\title{
Prevalence of diabetes mellitus and glucose metabolism disorders in the first degree relatives of type 2 diabetic patients
}

\author{
Karaman $\mathrm{A}^{1}$, Bayram $\mathrm{F}^{2}$, Gundogan $\mathrm{K}^{1}$, Ozsan $\mathrm{M}^{1}$, Karaman $\mathrm{H}^{3}$, Kelestimur $\mathrm{F}^{2}$ \\ Erciyes University Department of Internal Medicine, Kayseri, Turkey. drkaraman@hotmail.com
}

\begin{abstract}
Background and objectives: We designed this study to observe the DM prevalence, insulin resistance, beta cell reserve and the interaction of these parameters in the first degree relatives of Type 2 diabetic patients in Turkish population.

Methods: 125 subjects were included in the study. 25 subjects without the first degree diabetic relatives were selected as the control group; they were matched by age, BMI, socio-economical, cultural and environmental factors. (OGTT), (IVGTT), (GST), and (ITT), were performed on all subjects and controls.

Results: 12 (9.6 \%) DM and 23 (18. 4 \%) impaired glucose tolerance (IGT) cases of 125 subjects were diagnosed according to OGTT results. The mean BMI of diabetic subjects was significantly higher than of controls and subjects with normal glucose tolerance $(p<0.05)$. When compared to the control group, the mean AUCinsulin levels were significantly lower in diabetic subjects $(p<0.05)$. To observe the correlation between HOMAIR and KITT values, a statistically significant correlation was found $(p<0.05, r: 0.222)$. There was a deficiency in the Cpeptide response to glucagon stimulation in diabetic relatives ( $p<0.05, F: 4.59$ One Way ANOVA).

Conclusion: We demonstrated that the first degree relatives of Type 2 diabetic patients constitute a high risk group for DM, IGT and insulin resistance by using four different tests in Turkish population.

The significant finding(s) of the study: We demonstrated a high prevalence of glucose metabolism disorders in the relatives of type 2 diabetic patients.

This study adds our knowledge; insulin resistance and decreased beta cell reserve occur before diabetes mellitus begin in relatives (Tab. 5, Ref. 42). Full Text in PDF www.elis.sk.

Key words: diabetes mellitus, first degree relatives of type $2 \mathrm{DM}$, insulin resistance.
\end{abstract}

Type 2 diabetes mellitus is the most common type of diabetes and is characterized by variable degrees of insulin deficiency and resistance. Many patients with type 2 diabetes lose beta cell function over time and require insulin for glucose control. The prevalence of type 2 diabetes has risen alarmingly in the past decade linked in large part to the trends in obesity and sedentary lifestyle in the world (1).

Understanding the pathogenesis of type 2 diabetes is complicated by several factors (2). Patients present with a combination of varying degrees of insulin resistance and relative insulin deficiency, and it is likely that both contribute to type 2 diabetes (3). Furthermore, each of the clinical features can arise through genetic or environmental influences, making it difficult to determine the exact cause in an individual patient. Moreover, hyperglycemia it-

${ }^{1}$ Erciyes University Department of Internal Medicine, Kayseri, Turkey, ${ }^{2} \mathrm{Er}-$ ciyes University Department of Endocrinology and Metabolism, Kayseri, Turkey, and ${ }^{3}$ Erciyes University Department of Pathology, Kayseri, Turkey Address for correspondence: A. Karaman, Erciyes University Department of Internal Medicine, Alpaslan mahallesi, Emrah Caddesi, Beyoglu Apt. 21/3 Melikgazi, Kayseri, Turkey Postel Code 38030 Phone: +90.533 .4834197 , Fax: +90.352 .437527$

Acknowledgement: No support was taken to study including federal and industry support. self can impair pancreatic ß-cell function and exacerbate insulin resistance, leading to a vicious cycle of hyperglycemia causing a worsening metabolic state (4). Type 2 diabetes most likely represents a complex interaction among many genes and environmental factors. Monogenic causes of type 2 diabetes represent only a small fraction of cases and commonly inherited polymorphisms individually contribute to only small degrees of risk for, or protection from, diabetes. Most of the genetic risks for type 2 diabetes results from complex polygenic risk factors. First-degree relatives of patients with type 2 diabetes frequently have impaired nonoxidative glucose metabolism (indicative of insulin resistance) long before they develop type 2 diabetes (5). In addition, they may have beta-cell dysfunction, as evidenced by decrease in insulin and amylin release in response to glucose stimulation (6). Although many studies have been conducted in other countries, there is no study about relatives in Turkish population and there is no study that four different tests were done to the relatives in literature.

\section{Aim}

We designed the present study to observe the DM prevalence, insulin resistance, beta cell reserve and the interaction of these parameters in the first degree relatives of Type 2 diabetic patients in Turkish population with four different tests. 


\section{Subjects and methods}

Subjects

This study was performed in Erciyes University School of Medicine Department of Endocrinology and Metabolism. 125 firstdegree relatives of type 2 diabetic patients who were admitted to the hospital were enrolled in the study. Age and socio-economic matched 25 control subjects without any family history of diabetes mellitus participated in the study. The two groups were matched with respect to age, gender, BMI, social and economical environment. All subjects were healthy and taking no medication. There was no family history of any other endocrinological and metabolic disorders except DM. The pertinent clinical data of the two groups is shown in Table 1. The study protocol was approved by the Ethics Committee of the Erciyes University, School of Medicine. Informed patient consent was taken from the subjects.

\section{Design}

Body mass index (BMI) was calculated as weight $(\mathrm{kg})$ divided by height (m) squared. An oral glucose tolerance test (OGTT), intravenous glucose tolerance test (IVGTT), glucagon stimulation test (GST) and insulin tolerance test (ITT) were administered to all subjects. All tests were performed with an interval of one or two weeks for each subject. One-way ANOVA test, regression analysis was used as a statistical procedure. $\mathrm{p}<0.05$ was assessed as significant.

OGTT: After a 10-12 h overnight fast, the subjects ingested a solution containing 75 grams of glucose, and venous blood samples were obtained at $0,30,60,90$, and 120 minute for determination of plasma glucose, plasma insulin and C-peptide. Criteria for the diagnosis of diabetes, impaired fasting glucose, and impaired glucose tolerance (IGT) were made according to ADA criteria (7). $\mathrm{HOMA}_{\mathrm{IR}}, \mathrm{HOMA}_{\mathrm{ISI}}, \mathrm{AUC}_{\text {Glucose }}$ values were also calculated with data obtained from the OGTT results $(8,9,10)$.

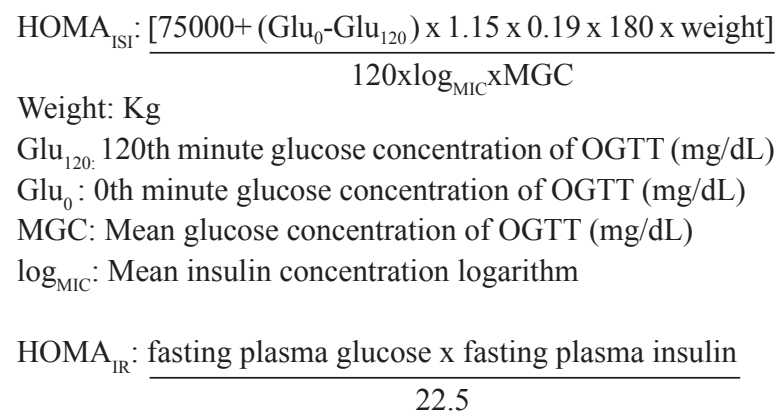

Fasting plasma glucose: $\mathrm{mmol} / \mathrm{L}$

Fasting plasma insulin: $\mu \mathrm{IU} / \mathrm{mL}$

Tab. 1. Demographic data of control and study groups.

\begin{tabular}{lllll}
\hline & Patients & \multicolumn{3}{c}{ Control } \\
\cline { 2 - 5 } & Male & Female & Male & Female \\
& $\mathrm{n}: 46$ & $\mathrm{n}: 79$ & $\mathrm{n}: 12$ & $\mathrm{n}: 13$ \\
\hline Age (year) & $34.2 \pm 6.6$ & $34.0 \pm 6.4$ & $34.8 \pm 3.3$ & $33.2 \pm 1.1$ \\
BMI (kg/m2) & $27.8 \pm 4.1$ & $27.8 \pm 5.6$ & $28.5 \pm 2.0$ & $25.4 \pm 2.5$ \\
\hline
\end{tabular}

$\mathrm{AUC}_{\text {Glucose }}:(\mathrm{Glu} 0+\mathrm{Glu} 30)$ x 15+(Glu30+Glu60) x15+ (Glu60+Glu90) x15+ (Glu90+Glu120) x15

Glu 0, 30, 60, 90,120: 0th, 30th, 60th, 90th, 120th minutes glucose concentration of OGTT

Glucagon stimulation test: After a 10-12 h overnight fast, baseline blood sample was taken. After injection of $1 \mathrm{mg}$ glucagon intravenously, blood sample was taken at the sixth minute to determine C-peptide levels $(11,12)$.

Insulin tolerance test: The aim of this test is to evaluate insulin resistance. After a $10-12 \mathrm{~h}$ overnight fast and after $0.1 \mathrm{IU} / \mathrm{Kg}$ regular insulin was injected intravenously, we took blood samples at $3,6,9,12,15,20$ th minutes. $200 \mathrm{~mL} 20 \%$ dextrose was given to subjects intravenously and the test was ended after symptomatic or measured hypoglycemia occurred. Using $0.693 / \mathrm{t} / 2$ formula, the falling speed of plasma glucose was calculated. This value is called $\mathrm{K}_{\mathrm{ITT}}$. $\mathrm{t} / 2$ shows the half time of plasma glucose from the beginning. Higher $\mathrm{K}_{\mathrm{ITT}}$ represents lower insulin resistance (13).

Intravenous glucose tolerance test: This test is used to distinguish type 1 and type 2 DM. If the baseline insulin level was high, the first phase insulin response was reduced and second phase insulin response was normal, we considered type $2 \mathrm{DM}(13,14,15)$.

After a 10-12 h overnight fast, two different vascular accesses were obtained. We injected $0.5 \mathrm{~g} / \mathrm{kg}$ (maximum $35 \mathrm{~g}$ ) $30 \% \mathrm{dex}-$ trose for 3-4 minutes. After infusion of dextrose, blood samples were collected to measure the plasma glucose level at 1, 3, 5, 10, $12,15,20,30$ th minutes. $\mathrm{K}_{\text {glucose }}$ values were calculated according to the formula below. The $\mathrm{K}_{\text {glucose }}$ value shows the glucose sent away from the plasma per minute (16). $t / 2$ shows the half time of plasma glucose from the beginning. This is calculated with SPSS regression analysis.

$$
\mathrm{K}_{\text {glucose }}=\frac{0.693 * 100}{(\mathrm{t} / 2)}
$$

The total of 1st and 3rd minutes insulin levels show the first phase insulin response. Fewer than $40 \mu \mathrm{IU} / \mathrm{mL}$ values show the first phase insulin deficiency and preclinical DM $(15,17)$. We calculated the AUC of 1, 3 and 5th minutes insulin levels, and statistically analyzed them between groups (18).

Glucose measurement was performed with the Konelab-60i auto analysis instrument, the insulin and C-peptide measurements were made by the RIA procedure in the Erciyes University School of Medicine Central Laboratory. Intraassay for insulin $80 \pm 2.8$ $\mu \mathrm{IU} / \mathrm{mL}$ (C.V.: $3.5 \%$ ), interassay $95 \pm 4.7 \mu \mathrm{IU} / \mathrm{mL}$ (C.V.: $4.9 \%$ ). intrassay for C-peptide $7.9 \pm 0.24 \mathrm{ng} / \mathrm{mL}$ (C.V.: $3.0 \%$ ), interassay $8.85 \pm 0.17 \mathrm{ng} / \mathrm{mL}$ (C.V.: $1.9 \%$ ). Statistical analysis was conducted with "SPSS 11.0" software.

\section{Results}

A total of 150 subjects participated in the study. 79 female $(63.2 \%), 46$ male $(36 \%)$ subjects were in the study group and $13(52 \%)$ female and $12(48 \%)$ male people were in the control group. All the groups underwent OGTT, IVGTT, ITT and GST. 
Tab. 2. Age and BMI data of groups.

\begin{tabular}{|c|c|c|c|c|c|c|c|c|c|}
\hline & \multirow[b]{2}{*}{ Group } & \multirow[b]{2}{*}{$\mathrm{n}$} & \multirow[b]{2}{*}{ Mean } & \multirow[b]{2}{*}{ Standard deviation } & \multirow[b]{2}{*}{ Standard error } & \multicolumn{2}{|l|}{$95 \% \mathrm{CI}$} & \multirow[b]{2}{*}{ Minimum } & \multirow[b]{2}{*}{ Maximum } \\
\hline & & & & & & Lower limit & Upper limit & & \\
\hline \multirow[t]{4}{*}{$\overline{\mathrm{BMI}}$} & $1^{*}$ & 12 & 31.5 & 6.0 & 1.74 & 27.65 & 35.35 & 22.6 & 40.4 \\
\hline & 2 & 23 & 27.9 & 3.8 & 0.79 & 26.28 & 29.59 & 18.4 & 35.1 \\
\hline & $3 *$ & 90 & 27.4 & 5.1 & 0.54 & 26.36 & 28.52 & 17.4 & 46.4 \\
\hline & $4^{*}$ & 25 & 26.8 & 2.7 & 0.54 & 25.76 & 28.02 & 21.4 & 33.6 \\
\hline \multirow[t]{4}{*}{$\overline{\mathrm{AGE}}$} & 1 & 12 & 37.8 & 5.9 & 1.70 & 34.07 & 41.59 & 29.0 & 45.0 \\
\hline & 2 & 23 & 35.4 & 5.6 & 1.17 & 32.98 & 37.88 & 25.0 & 45.0 \\
\hline & 3 & 90 & 33.3 & 6.5 & 0.69 & 31.94 & 34.70 & 22.0 & 45.0 \\
\hline & 4 & 25 & 34.0 & 2.5 & 0.50 & 32.94 & 35.05 & 31.0 & 42.0 \\
\hline
\end{tabular}

*: $<<0.05$, F: 2.926, One-Way ANOVA

Tab. 3. HOMA ${ }_{\mathrm{IR}}, \mathrm{HOMA}_{\mathrm{ISI}}, \mathrm{AUC}_{\mathrm{Glucose}}, \mathrm{AUC}_{\mathrm{Insulin}}, \mathrm{K}_{\mathrm{ITT}}$, Baseline c-peptide, 6th minute c-peptide values of groups.

\begin{tabular}{|c|c|c|c|c|}
\hline \multirow[t]{2}{*}{ Parameters } & \multicolumn{4}{|c|}{ Groups } \\
\hline & $1(\mathrm{n}: 12)$ & $2(\mathrm{n}: 23)$ & $3(\mathrm{n}: 90)$ & $4(\mathrm{n}: 25)$ \\
\hline & Mean (SD) & Mean (SD) & Mean (SD) & Mean (SD) \\
\hline$\overline{\text { HOMA }_{I R}}$ & $3.40(2.99)$ & $2.44(1.79)$ & $2.28(2.06)$ & $0.91(0.64)$ \\
\hline $\mathrm{HOMA}_{\mathrm{ISI}}$ & $195.5(42.86)$ & $295.6(81.07)$ & $400.2(167.44)$ & $455.1(167.44)$ \\
\hline $\mathrm{AUC}_{\text {Glucose }}$ & $26242.5(3165.16)$ & $18052.1(2177.33)$ & $14639.4(2513.18)$ & $12955.8(2429.35)$ \\
\hline $\mathrm{AUC}_{\text {Insulin }}$ & $138.35(96.18)$ & $165.69(107.70)$ & $342.49(346.47)$ & 459.23 (191.56) \\
\hline $\mathrm{K}_{\mathrm{ITT}}$ & $0.93(0.38)$ & $1.21(0.38)$ & $1.42(0.40)$ & $1.56(0.20)$ \\
\hline Baseline c-peptide & $2.23(0.69)$ & $2.84(1.01)$ & $2.51(0.96)$ & $2.11(0.40)$ \\
\hline 6th minute c-peptide & $3.26(1.07)$ & $6.51(2.96)$ & $6.28(2.33)$ & $6.66(1.40)$ \\
\hline
\end{tabular}

Tab. 4. Correlation analysis.

\begin{tabular}{|c|c|c|c|c|c|c|c|}
\hline & $\begin{array}{l}\text { Statistical } \\
\text { analysis }\end{array}$ & $\mathrm{AUC}_{\text {Glucose }}$ & $\mathrm{AUC}_{\mathrm{Ins}}$ & $\begin{array}{c}\text { GST } \\
0 \text { to } 6 \text { th minute } \\
\text { C-peptide }\end{array}$ & $\begin{array}{c}\text { GST } \\
\text { Baseline } \\
\text { C-peptide }\end{array}$ & $\begin{array}{c}\text { GST } \\
\text { 6th minute } \\
\text { C-peptide }\end{array}$ & $\begin{array}{c}\text { IVGTT } \\
\text { First phase } \\
\text { insulin secretion }\end{array}$ \\
\hline \multirow{2}{*}{$\mathrm{AUC}_{\text {Glucose }}$} & $\mathrm{r}$ & 1.0 & -0.35 & -0.42 & 0.09 & -0.337 & 0.462 \\
\hline & $\mathrm{p}$ & - & 0.001 & 0.000 & 0.433 & 0.005 & 0.000 \\
\hline \multirow{2}{*}{$\mathrm{AUC}_{\text {Insülin }}$} & $\mathrm{r}$ & -0.350 & 1.000 & 0.165 & -0.081 & 0.088 & -0.347 \\
\hline & $\mathrm{p}$ & 0.001 & - & 0.237 & 0.562 & 0.532 & 0.001 \\
\hline$\overline{\mathrm{GST}}$ & $\mathrm{r}$ & -0.426 & 0.165 & 0.000 & 0.094 & 0.929 & 0.020 \\
\hline 0 to $6^{\text {th }}$ minute c-peptide & $\mathrm{p}$ & 0.000 & 0.237 & - & 0.446 & 0.000 & 0.887 \\
\hline GST & $\mathrm{r}$ & 0.096 & -0.081 & 0.094 & 1.000 & 0.456 & 0.247 \\
\hline Baseline c-peptide & $\mathrm{p}$ & 0.433 & 0.562 & 0.446 & - & 0.000 & 0.068 \\
\hline GST & $\mathrm{r}$ & -0.337 & 0.088 & 0.929 & 0.456 & 10.000 & 0.122 \\
\hline $6^{\text {th }}$ minute c-peptide & $\mathrm{p}$ & 0.005 & 0.532 & 0.000 & 0.000 & - & 0.381 \\
\hline IVGTT & $\mathrm{r}$ & 0.462 & -0.347 & 0.020 & 0.247 & 0.122 & 10.000 \\
\hline First phase insulin secretion & $\mathrm{p}$ & 0.000 & 0.001 & 0.887 & 0.068 & 0.381 & - \\
\hline
\end{tabular}

Mean ages of the subjects were $34.1 \pm 6.5$ years; the BMI was $27.8 \pm 5.1 \mathrm{~kg} / \mathrm{m}^{2}$ (Tab. 1). We found DM $6.9 \%, 14.3 \%, 33.3 \%$ and IGT $18.4 \%, 14.3 \%, 66.7 \%$ in relatives whose mothers, fathers, siblings had type 2 DM respectively. All participants were evaluated according to OGTT results in four groups:

Group 1: Relatives diagnosed DM in the study.

Group 2: Relatives diagnosed IGT.

Group 3: Relatives diagnosed normal glucose tolerance

Group 4: Control group with normal glucose tolerance

Mean age and BMI are shown in Table 2. Group 1 had significantly higher mean BMI values than the group 3 and $4(\mathrm{p}<$ 0.05) (Tab. 2).

According to OGTT results: 12 of 125 relatives (9.6\%) have DM and 23 of them (18.45\%) have IGT, 6 of them (4.8\%) have impaired fasting glucose (IFG)

$\mathrm{HOMA}_{\mathrm{ISI}}, \mathrm{HOMA}_{\mathrm{IR}}, \mathrm{AUC}_{\text {glucose }}$ values were calculated as shown in the subjects and method section. $\mathrm{HOMA}_{\mathrm{IR}}$ values were found $3.4 \pm 2.9,2.4 \pm 1.8,2.3 \pm 2.1$ and $09 \pm 0.6$ in the groups $1,2,3,4$ respectively. The statistical analysis of these results showed that $\mathrm{HOMA}_{\mathrm{IR}}$ value of the control group was significantly lower than the others ( $p<0.005$, Dunnet - test) (Tab. 3).

$\mathrm{HOMA}_{\text {ISI }}$ values were found $195.5 \pm 42.8,295.6 \pm 81$, $400.2 \pm 150.7,455.1 \pm 67.4$ in the groups $1,2,3,4$ respectively. In the statistical analysis, $\mathrm{HOMA}_{\mathrm{ISI}}$ values were lower significantly in the group 1 than in the group 3 and 4 . HOMA $A_{\text {ISI }}$ values were also significantly lower in the group 2 than in the group 3 and 4 $(p<0.005$ F: 11.38 One Way - ANOVA) (Tab. 3).

$\mathrm{AUC}_{\text {glucose }}$ values were measured $26242 \pm 3165,18052 \pm 2177$, $14639 \pm 2513,12955 \pm 2419$ in the groups $1,2,3,4$ respectively. There was a significant difference in all groups (Tab. 3$)(\mathrm{p}<0.05)$.

According to IVGTT, we found an early insulin secretion (first phase) insufficiency in 21 subjects of 125 (16.8\%), and we determined 5 subjects $(23.8 \%)$ with DM, 6 subjects $(28.6 \%)$ with IGT out of 21 subjects. If $\mathrm{K}_{\text {glucose }}$ values were below $1 \%$, they showed 
a definite diagnosis of $\mathrm{DM}(10,16,35)$. We diagnosed DM in 9 patients (7.2\%) by IVGTT. We found 3 DM (33.3\%) and 3 IGT $(33.3 \%)$ in the 9 patients by using OGTT.

We calculated AUC of the insulin level at first, third and fifth minutes after glucose infusion in IVGTT. The measured insulin level, which appears after calculating the under curve area, is an indicator of the acute insulin response of beta cells. Group's AU$\mathrm{C}_{\text {insulin }}$ averages are shown in the table 8 . When these results were compared to the control group, $\mathrm{AUC}_{\text {insulin }}$ level averages were much lower in the diabetic and IGT relatives $(\mathrm{p}<0.05)($ Tab. 3$)$.

ITT results: $\mathrm{K}_{\text {ITT }}$ values were calculated according to ITT data and show in unit time the glucose amount that is kept away from the environment. $\mathrm{K}_{\mathrm{ITT}}$ values and statistical analysis can be seen in the table 9. Between the group 1 and the groups 3, 4 and between the group 2 and 4 significant differences were found $(\mathrm{p}<0.05)$ (Tab. 3 ).

GST results: Sixth minutes C-peptide levels of the diabetic relatives were above $0.0513 \mathrm{ng} / \mathrm{mL}$. Within the patients diagnosed with diabetes, the same level and above values were assessed as type 2 diabetes $(12,16)$ (Tab. 3$)$. When 6th minute c-peptide averages were compared between the first group and other groups, there was a significant statistical difference. The 6th minute C-peptide averages of diabetic relatives were much lower than the other groups (Tab. 3). When the average increase from the baseline to 6th minute C-peptide levels were compared, there was a significant statistical difference between the groups and there was a deficiency in the C-peptide response to glucagon stimulation in diabetic relatives ( $p<0.05, \mathrm{~F}: 4.59$ One Way ANOVA).

Correlation analysis: To establish whether there is a correlation between $\mathrm{HOMA}_{\mathrm{IR}}$ and $\mathrm{K}_{\mathrm{ITT}}$, a non-parametric Pearson test was carried out and a significant statistical correlation was seen $(\mathrm{p}<0.05 \mathrm{r}: 0.222)$. There is a statistically significant correlation between HOMA ${ }_{\text {ISI }}$ and $\mathrm{K}_{\text {ITT }}$ values $(\mathrm{p}<0.05 \mathrm{r}$ : 0.333). Based on GST, a statistically significant correlation was found between the average increase from baseline to 6th minute C-peptide levels and 6th minute C-peptide measurements (Tab. 4).

\section{Discussion}

Diabetes Mellitus is a group of metabolic deficiencies in which insulin secretion and action or both leads to hyperglycemia. It is known that type $2 \mathrm{DM}$ frequently shows a resistance to the effect of insulin $(19,20)$. Although the aetiology is not clear, there is no autoimmune destruction of the beta cell in type $2 \mathrm{DM}$. Researches carried out on family members with diabetes and twins with diabe- tes confirmed that hereditary factors play a role in type $2 \mathrm{DM}$. Due to the latest developments in molecular biology in recent years, genetics have provided a higher clarity, especially in type $2 \mathrm{DM}$.

The effects of genetic factors in type $2 \mathrm{DM}$ is more evident than in type $1 \mathrm{DM}$. The concordance in monozygotic twins is $60-80 \%$. Obesity (especially truncal obesity), lifestyle, IGT and having a diabetic relative are some of the risk factors for type 2 DM. The first degree relatives of diabetic patients with IGT have a $30-40 \%$ risk of diabetes mellitus development $(21,22,23)$.

Many studies have been carried out on the relationship between type $2 \mathrm{DM}$ and genetics. However, in Turkey, published studies of patients with type $2 \mathrm{DM}$ and other glucose metabolism disorders are scarce. In our study, we tried to clarify this. Apart from this, various tests were carried out in this study, giving patients information concerning their insulin resistance and beta cell reserve; these factors were compared to each other. Similar studies have been carried out previously, but in our study we went one step further; each patient underwent four tests and correlation analyses were carried out.

At the same time, patients were put into subgroups and investigated according to relatives with DM. Subjects whose siblings and fathers were diabetic had a higher risk for developing DM. However, for glucose metabolism assessments to be carried out, further studies with more patients are required. When compared, subjects whose fathers had DM had a significantly higher risk of $\mathrm{DM}(\mathrm{p}<0.005$, One Way ANOVA).

Our study examines different factors than those in the literature. First, when compared to previous studies, this study was carried out on a younger group and previous studies have limited data about glucose metabolism dysfunction. The second different point is that Pontirolli et al examined only the siblings of patients with diabetes (24). Grill et al examined only brothers of patients with diabetes, but we choose a much wider relative group: siblings in some, mothers in some and fathers in some came across with diabetes (14). We found a much higher percentage of diabetes in siblings compared to both Grill and Pontirolli's studies. However, we found that BMI is much higher in diabetic relatives compared to non-diabetic groups.

Studies show that there is an insulin resistance in the first degree relatives of diabetic patients although they were not obese (25). The existence of the association between Type 2 diabetes and obesity has been known for many years, and as the body fat percentage rises, the development of diabetes also rises. In this study, BMI of relatives with diabetes was higher compared to non-

Tab. 5. Studies about the first degree relatives of type 2 diabetic patients.

\begin{tabular}{|c|c|c|c|c|c|c|}
\hline & $\mathrm{n}$ & Tests were done & $\mathrm{DM}$ & IGT & $\begin{array}{c}\text { BMI } \\
\text { (Diabetic relatives) }\end{array}$ & $\begin{array}{c}\text { Age } \\
\text { (Diabetic relatives) }\end{array}$ \\
\hline Karaman & 125 & $\begin{array}{l}\text { OGTT, IVGTT, } \\
\text { GST, ITT }\end{array}$ & $12(9.6 \%)$ & $23(18.4 \%)$ & 27.8 & 34.1 \\
\hline $\begin{array}{l}\text { Pontirolli } \\
\text { (only siblings) }\end{array}$ & 130 & OGTT & $24(18.4 \%)$ & $31(23.8 \%)$ & 29.6 & 57.2 \\
\hline $\begin{array}{l}\text { Grill } \\
\text { (only male relatives) }\end{array}$ & 162 & OGTT & $52(3.2 \%)$ & $121(7.5 \%)$ & 26.5 & 46.6 \\
\hline Costa & 209 & OGTT & $21(10.2 \%)$ & $49(20.5 \%)$ & 28.2 & 50.0 \\
\hline
\end{tabular}


diabetic relatives. Volk et al. carried out a study on 154 healthy immediate family members of patients with Type 2 diabetes, of which 97 had no immediate family members with diabetes as a control group. Volk et al, performed OGTT and hyperinsulinemic - euglycemic clamp test in each case. They determined that insulin secretion had increased, yet, in the early phase, insulin secretion decreased in immediate family members. They found hyperinsulinemia and a decreased or delayed early insulin secretion was determined in family members who were obese (26). In our study, when we compared relatives with diabetes and relatives with normal glucose tolerance and the control group, BMI values significantly increased in the diabetic group.

In our study, we found the $\mathrm{AUC}_{\text {glucose }}$ values of the study groups (whether the glucose metabolism is distorted or not) were significantly higher than of the control group $(p<0.005$, One Way ANOVA). Therefore it can be said that distortion of glucose metabolism can occur whether clinical diabetes or IGT is diagnosed or not in the the first degree relatives of type 2 diabetic patients. Previous studies reported that high DM, IGT percentages, increased insulin resistance and lessened insulin sensitivity are seen in immediate relatives of diabetic patients $(25,27,28)$. It has been reported that in normoglycemic relatives, insulin resistance has an increased cardiovascular risk (29). In this study we determined that there is a high glucose load in the area under the curve in relatives although their OGTT results are normal. This high glucose load causes glucose toxicity, insulin resistance and DM in relatives. As mentioned above, our study shows that relatives with DM have significantly higher HOMA $_{\mathrm{IR}}$ values in their IGT and normal glucose tolerance compared to the control group. It shows that increased glucose load causes insulin resistance. In previous studies, the existence of insulin resistance in some relatives with normal glucose tolerance was deduced $(20,26,30)$, but the escalated glucose load, that we discovered in this study, was never mentioned before. This is a very important point since even in relatives with normal glucose tolerance compared to the control group, the glucose load is quite high and their insulin resistance (valued using the HOMA method) is increased. These individuals may appear as though their OGTT and glucose tolerance are normal, but it can be predicted that in later life they carry the risk of developing diabetes.

When a statistical analysis is made for groups, $\mathrm{HOMA}_{\mathrm{IR}}$ average, a significant increase was seen in the groups 1, 2 and 3 compared to the control group ( $\mathrm{p}<0.05$, Dunnet-test) (Tab. 5). Insulin resistance was higher in all groups whether glucose tolerance was normal or not. Insulin resistance raises two important clinical concerns: First, dysfunction as a result of deficient insulin effect (DM, IGT, delayed growth and lipoatrofia). And second, conditions that develop as a result of excessive insulin effect (acanthosis nigricans, ovarian hyperandrogenism) $(31,32,33,34)$. Insulin resistance can be seen in many situations such as, stress, hunger, ketoacidosis, cirrhosis, uremia, hyperglycemia (glucose toxicity), obesity, type $2 \mathrm{DM}$, atherosclerotic heart diseases, dyslipidemia, polycystic ovary syndrome. Apart from those cases, in $25 \%$ of healthy people insulin resistance can occur, and in a high percentage of these people it is believed that they can also develop type $2 \mathrm{DM}$, hypertension, dyslipidemia and cardiovascular diseases.
HOMA $_{\text {ISI }}$ values calculated by using OGTT data show the insulin sensitivity of tissues (9). Differences among $\mathrm{HOMA}_{\mathrm{ISI}}$ values of the groups show that insulin sensitivity of tissues is decreased in the first degree relatives ( $p<0.005 \mathrm{~F} ; 11.38$ One Way - ANOVA) (Tab. 3). Some genetic mutations (in the insulin receptor gene and post receptor signal transmission) and environmental factors cause insulin resistance by affecting insulin sensitivity. Besides this, malnutrition, obesity, ageing, pregnancy, hyperglycemia, autoantibody develops against the insulin receptors causing decreased insulin sensitivity.

When $\mathrm{K}_{\text {ITT }}$ values were evaluated, significant differences were found between the group 1 and group 3, between the group 1 and group 4 and between the group 2 and group $4 \mathrm{p}<0.05$ ) (Tab. 3). This result shows that there was insulin resistance, and that this is one of the most important factors in the beginning stages of diabetes in the first degree relatives of type 2 diabetic patients. Schmitz et al evaluated 15 relatives of type 2 diabetic patients and 13 subjects as a control group. They determined that serum insulin concentrations of relatives were significantly higher when compared to the control group. When insulin sensitivity was compared to the control group, they determined that the sensitivity was $20 \%$ lower in relatives (30). Although they found similar results to our study, we found the first phase insulin secretion deficiency along with insulin resistance in relatives.

According to our GST result, baseline C-peptide levels were higher than $0.0513 \mathrm{ng} / \mathrm{mL}(0.17 \mathrm{pmol} / \mathrm{L})$ and increased C- peptide level in the 6th minute was higher than $0.0211 \mathrm{ng} / \mathrm{mL}(0,07$ $\mathrm{pmol} / \mathrm{L}$ ) in patients with DM. Because C-peptide response to glucagon stimulation over a certain level $(0.0211 \mathrm{ng} / \mathrm{nL})$, we concluded that all the patients with diabetes also had type $2 \mathrm{DM}$ in our study (12) When the groups, 6th minute C-peptide mean values were compared between the first and other groups, the diabetic group's values were significantly lower than in the other groups. The GST is one of the bests test to determine the first phase insulin secretion dysfunction and beta cell reserve in pathogenesis of type $2 \mathrm{DM}$.

We found a correlation between $\mathrm{AUC}_{\text {glucose }}$ and 6th minute C-peptide levels of glucagon test (Tab. 4). These and previously mentioned correlations showed that an increased glucose load and C-peptide response stimulated by glucagon (shows beta cell reserve) were associated with each other. Basic insulin levels of type 2 diabetic patients can be increased, decreased or normal. However, in the early stages of illness, loss of the first phase insulin secretion almost always occurs. It was suggested that in the development of type $2 \mathrm{DM}$, the first finding is supposed to be early phase insulin secretion malfunction $(16,17,22,23)$. We found that the average of $\mathrm{AUC}_{\text {insulin }}$ levels was statistically lower compared to the control group $(\mathrm{p}<0.05$ One Way ANOVA) (Tab. 3). The patient whose total insulin level measurement in the first and third minutes was under $40 \mu \mathrm{IU} / \mathrm{mL}$ is $16.8 \%$ of all relatives. That means that the first phase insulin secretion decreased in $16.8 \%$ of all relatives in our study. We found 5 clinical DM (23.8 \%) and 6 IGT (28.6\%) in 21 patients with the first phase insulin secretion deficiency. As the tables show, we found a distortion of glucose metabolism in $52.4 \%$ (the total of DM and IGT percentage) of patients who have the first phase insulin secretion deficiency. Galvin et al (18) 
reported that there was a latent period in the pathogenesis of type $1 \mathrm{DM}$. In this period before hyperglycemia, beta cell damage and progressively decreasing first phase insulin response is seen and a similar mechanism can be seen in type $2 \mathrm{DM}$. We show in our study that the assessment of insulin resistance $\mathrm{HOMA}_{\mathrm{IR}}$ values can be used instead of ITT; this process can be carried out much more easily and without risk.

Coifman et al (36) reported that there is a real hyperinsulinemia and hyperproinsulinemia, which is an evidence of insulin resistance and there is no structural defect in beta cells in the first degree relatives of type 2 diabetic patients. Bogardus et al (15) reported that a major risk factor for diabetes is a relatively decreased acute insulin response in Pima Indians in the State of Arizona, USA. Starting from this point, not only in the Pima Indians, but all individuals whose relatives are diabetic, we can say have an increased risk of a decreased acute insulin response OR risk of insulin resistance and distorted first phase insulin secretion.

Although some studies showed a high DM prevalence, beta cell dysfunction and impaired glucose metabolism in the first degree relatives of type 2 diabetic patients, we showed a high rate of DM, increased glucose load, increased insulin resistance and distorted first phase insulin secretion by using four different tests $(37,38,39)$ (Tab. 5). We also showed that this defect appeared in younger age when compared to previous studies.

Some population differences (genetic, environmental or some dietary factors) may cause the variation on DM, IGT and IFG prevalence. For example; prevalence of IFG is too low compared toIGT prevalence in Turkey opposite to findings from Anglo-Saxon European population.

Satman et al (40) and Keleştimur et al (41) reported the prevalence of DM with TURDEP study but there is no study about the relatives of diabetic patients in Turkey. One of the main aims of our study was to determine the glucose metabolism of the first degree relatives of type 2 diabetic patients in Turkey, and we saw these people were under a high risk of DM and IGT. This people, even though they have normal glucose tolerance, may develop diabetes due to an increased glucose load, increased insulin resistance and distorted first phase insulin secretion. These people need to be monitored to prevent diabetes in the future.

\section{References}

1. Engelgau, MM, Geiss, LS, Saaddine, JB et al. The evolving diabetes burden in the United States. Ann Intern Med 2004; 140: 945.

2. Stumvoll, M, Goldstein, BJ, van Haeften, TW. Type 2 diabetes: principles of pathogenesis and therapy. Lancet 2005; 365: 1333.

3. Beck-Nielsen, H, Groop, LC. Metabolic and genetic characterization of prediabetic states. Sequence of events leading to non-insulin-dependent diabetes mellitus. J Clin Invest 1994; 94: 1714.

4. Robertson RP. Antagonist: diabetes and insulin resistance - philosophy, science, and the multiplier hypothesis. J Lab Clin Med 1995; 125: 560.7

5. Li, Y, Xu, W, Liao, Z et al. Induction of long-term glycemic control in newly diagnosed type 2 diabetic patients is associated with improvement of beta-cell function. Diabetes Care 2004; 27: 2597.
6. Eriksson, J, Franssila-Kallunki, A, Ekstrand, A et al. Early metabolic defects in persons at increased risk for non-insulin-dependent diabetes mellitus. N Engl J Med 1989; 321: 337.

7. Knowles, NG, Landchild, MA, Fujimoto, WY, Kahn, SE. Insulin and amylin release are both diminished in first-degree relatives of subjects with type 2 diabetes. Diabetes Care 2002; 25: 292.

8. Report of the Expert Committee on the Diagnosis and Classification of Diabetes Mellitus. Diabetes Care January 2002 25: s5-s20.

9. Kuroe A, Fukushima M, Usami M. Impaired beta-cell function on insulin sensitivity in Japanese subjects with normal glucose tolerance. Diabetes Res Clin Pract 2003; 59: 71-77.

10. Stumvoll M, Mitrakou A, Pimenta W et al. Use of oral glucose tolerance test to assess insulin sensitivity. Diabetes Care 2000; 23: 295-301.

11. Matthews DR, Hosker JP, Rudenski AS et al. Homeostasis model assessment: Insulin resistance and $\beta$-cell function from fasting plasma glucose and insulin concentrations in man. Diabetologia 1985; 28: 412-419.

12. Wang T, Xiao XH, Li WH, Wang H, Sun Q, Yuan T, Yang GH. Effects of glucagon on islet beta cell function in patients with diabetes mellitus. Chin Med Sci J. 2008; 23 (2): 117-120.

13. Service FJ, Rıza RA, Zimmerman BR et al. The classification of diabetes by clinical and c-peptide criteria. Diabet Care 1997; 20: 198-207.

14. Graci S, Barata R, Degano C et al. The intravenous insulin tolerance test is an accurate method for screening a general population for insulin resistance and related abnormalities. J Endocrinol Invest 1999; 22: 472-475.

15. Grill V, Persson G, Carlsson $\mathbf{S}$ et al. Family history of diabetes in middle-aged Swedish men is a gender unrelated factor which associates with insulinopenia in newly diagnosed diabetic subjects. Diabetologia 1999; 42: 15-23.

16. Bogardus C, Tataranni PA. Reduced early insulin secretion in the etiology of the Type-2 diabetes mellitus in PIMA Indians. Diabetes 2002; 51: S262-264.

17. Festa A, Williams K, Hanley AJ, Haffner SM. Beta-cell dysfunction in subjects with impaired glucose tolerance and early type 2 diabetes: comparison of surrogate markers with first-phase insulin secretion from an intravenous glucose tolerance test. Diabetes 2008; 57 (6): 1638-44.

18. Castaner MF, Biarnes J, Camps I et al. Beta-cell dysfunction in firstdegree relatives of patients with non-insulin dependent diabetes mellitus. Diabetologia 1995; 38: 953-959.

19. Galvin P, Ward G, Walters J et al. A simple method for quantitation of insulin sensitivity and insulin release from an intravenous glucose tolerance test. Diabet Med 1992; 9: 921-928.

20. Zimmet PZ. The pathogenesis and prevention of diabetes in adults. Diabetes Care 1995; 18: 1050-1064.

21. Lillioja S, Mott DM, Spraul M et al. Insulin resistance and insulin secretory dysfunction as precursors of non-insulin dependent diabetes mellitus. Prospective study of Pima Indians. N Engl J Med 1993; 329: 1988-1992.

22. James B, Meigs L, Cuppies A et al. Parental transmission of type 2 diabetes, the Framingham offspring study. Diabetes 2000; 49: 2201-2207.

23. Gautier JF, Wilson C, Weyer $\mathbf{C}$ et al. Low acute insulin secretory responses in adult's offspring of people with early onset type 2 diabetes. Diabetes 2001; 50: 1828-1833.

24. Axelsen M, Eriksson JW, Taskinen MR et al. Postprandial hypertriglyceridemia and insulin resistance in normoglycemic first-degree relatives of patients with type 2 diabetes. Ann Intern Med 1999; 131: 27-31. 
25. Pontirolli AE, Monti LD, Costa $S$ et al. In middle-aged siblings of patient with Type 2 diabetes mellitus normal glucose tolerance is associated with insulin resistance and with increased insulin secretion. The SPIDER study. Eur J Endocrinol 2000; 143: 681-686.

26. Iskhikawa M, Pruneda ML, Huet BA et al. Obesity independent hyperinsulinemia in nondiabetic first degree relatives of individuals with Type-2 diabetes. Diabetes 1998; 47: 788-792.

27. Volk A, Renn W, Overkamp D et al. Insulin action and secretion in healthy glucose tolerant first degree relatives of patients with type-2 diabetes mellitus. Influence of body weight. Exp Clin Endocrinol Diabetes 1999; 107: 140-147.

28. Costa A, Rios M, Casamitjana R et al. High prevalence abnormal glucose tolerance and metabolic disturbances in first degree relatives of NIDDM patients. Diabetes Res Clin Pract 1998; 41: 191-196.

29. Shaw JTE, Purdie DM, Neil HAW et al. The relative risk of hyperglycemia, obesity and dyslipidemia in the relatives of patients with Type-2 diabetes mellitus. Diabetologia 1999; 42: 24-27.

30. Shaw JTE, Levy JC, Turner RC. The relationship between the insulin resistance syndrome and insulin sensitivity in the first-degree relatives of subjects with non-insulin dependent diabetes mellitus. Diabetes Res Clin Pract 1998; 42: 91-99.

31. Schmitz O, Porksen N, Nyholm B et al. Disorderly and nonstationary insulin secretion in relatives of patients with NIDDM. Am J Physiol 1997; 272: E218-E226.

32. Reaven GM. Role of insulin resistance in human disease. Diabetes 1988; 37: 1595-1607.

33. Unluhizarci K, Kelestimur F, Bayram F. Insulin-sensitizing agents and their effect on adrenal androgens. Fertile Sterile 2000; 74: 1058-1059.
34. Kelestimur F, Unluhizrci K, Bayram F et al. Metformin and polycystic ovary syndrome. Clin Endocrinol 2000; 52: 244-246.

35. Ovale F, Azziz R. Insulin resistance, polycystic ovary syndrome and type 2 diabetes mellitus. Fertil Steril 2002; 77: 1095-1105.

36. Tankova T, Dakovski L, Kirilov $G$ et al. Intravenous glucose tolerance test and anti-GAD65 antibodies in the diagnosis of the type of diabetes mellitus. Pract Diab Int 2003; 20: 13-17.

37. Coifman R, Dalbosco IS, Russo EMK. Specific insulin and proinsulin in normal glucose tolerant first-degree relatives of NIDDM patients. Braz J Med Biol Res 1999; 32: 67-72.

38. Siewert S, Filipuzzi S, Codazzi L, Gonzalez I, Ojeda MS. Impact of metabolic syndrome risk factors in first-degree relatives of type 2 diabetic patients. Rev Diabet Stud. 2007 Fall; 4(3): 177-84. Epub 2007 Nov 10.

39. Stadler M, Pacini G, Petrie J, Luger A, Anderwald C; on behalf of the RISC Investigators. Beta cell (dys)function in non-diabetic offspring of diabetic patients. Diabetologia 2009, Sep 12.

40. Crispim D, Canani LH, Gross JL, Tschiedel B, Souto KE, Roisenberg I. Familial history of type 2 diabetes in patients from Southern Brazil and its influence on the clinical characteristics of this disease. Arq Bras Endocrinol Metab 2006; 50 (5): 833-835.

41. Satman I, Yilmaz T, Sengül A, Salman S, Salman F, Uygur S, Bastar I, Tütüncü Y, Sargin M, Dinççag N, Karsidag K, Kalaça S, Ozcan C, King H. Population-based study of diabetes and risk characteristics in Turkey: results of the turkish diabetes epidemiology study (TURDEP). Diabet Care 2002; 25 (9): 1551-1556.

42. Kelestimur F, Cetin M, Paşaoğlu H, Coksevim B, Cetinkaya F, Unlühizarci K, Unal S, Köker AH. The prevalence and identification of risk factors for type 2 diabetes mellitus and impaired glucose tolerance in Kayseri, central Anatolia, Turkey. Acta Diabet 1999; 36 (1-2): 85-91.

Received December 16, 2010. Accepted February 20, 2012. 